CHRISTINE DE PIZAN

AND THE

FIGHT FOR FRANCE

ฟ้. 


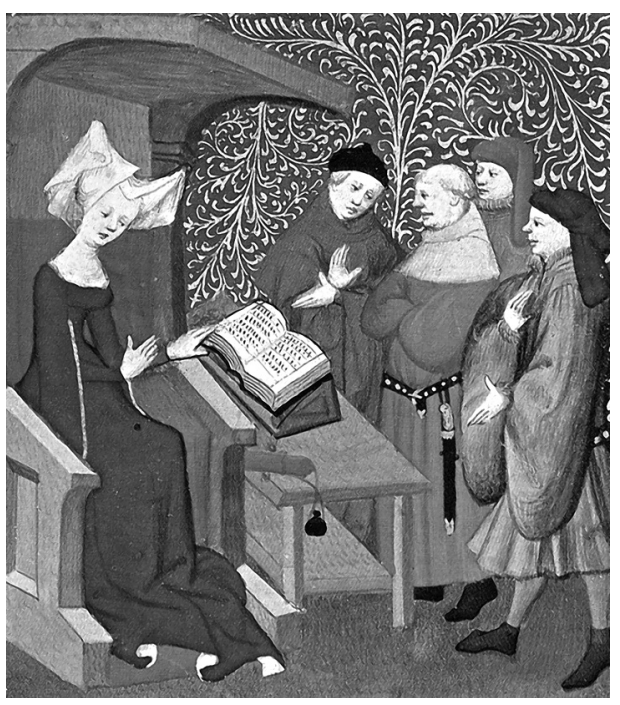




\section{CHRISTINE DE PIZAN}

AND THE

\section{FIGHT FOR FRANCE} ลै้

Eracy Chdams 
Library of Congress Cataloging-in-Publication Data

Adams, Tracy, 1959- , author.

Christine de Pizan and the fight for France / Tracy Adams.

$$
\text { p. } \mathrm{cm}
$$

Summary: "Evaluates Christine de Pizan's literary engagement with fifteenth-century French politics. Locates the writer's works within a detailed narrative of the complex history of the dispute between the Burgundians and the Armagnacs, the two largest political factions"Provided by publisher.

Includes bibliographical references and index. ISBN 978-0-27I-0507I-3 (cloth : alk. paper)

I. Christine, de Pisan, approximately I364-approximately I43I-Political and social views.

2. Christine, de Pisan, approximately I364-approximately I43I-Criticism and interpretation.

3. Politics and literature-France-History-To I5OO.

4. Political poetry, French-History and criticism. 5. France-History-Charles VI, I380-I422.

I. Title.

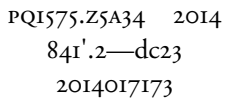

Copyright $(2014$ The Pennsylvania State University All rights reserved

Printed in the United States of America

Published by The Pennsylvania State University Press, University Park, PA I6802-I003

The Pennsylvania State University Press is a member of the Association of American University Presses.

It is the policy of The Pennsylvania State University Press to use acid-free paper. Publications on uncoated stock satisfy the minimum requirements of American National Standard for Information Sciences-Permanence of Paper for Printed Library Material, ANSI Z39.48-I992.

This book is printed on paper that contains $30 \%$ post-consumer waste.

Frontispiece: Miniature from British Library, Harley MS 443I, fol. 259v. 
FOR HELENA OLIVER (I965-20I3)

A woman of uncommon valor 
